\title{
Partisipasi Anggota Kopma : Pelatihan, Kualitas dan Kreatifitas
}

\author{
Nungky Kusuma Dewi \\ e-mail: nungky.kusuma658@gmail.com \\ Lilik Sri Hariani \\ e-mail: liliksrihariani@unikama.ac.id \\ Riril Mardiana Firdaus \\ e-mail: ririlmardiana@unikama.ac.id
}

(Program Studi Pendidikan Ekonomi, Fakultas Ekonomika dan Bisnis, Universitas Kanjuruhan, Malang)

\begin{abstract}
ABSTRAK : Penelitian ini bertujuan untuk Menganalisis Pengaruh Pelatihan Perkoperasian, Kualitas Pelayanan dan Kreatifitas Pengurus Terhadap Partisipasi Anggota di Kopma Universitas Negeri Malang, Menganalisis Pengaruh Pelatihan Perkoperasian Terhadap Partisipasi Anggota di Kopma Universitas Negeri Malang, Menganalisis Pengaruh Kualitas Pelayanan Terhadap Partisipasi Anggota di Kopma Universitas Negeri Malang, dan Menganalisis Pengaruh Kreatifitas Pengurus Terhadap Partisipasi Anggota di Kopma Universitas Negeri Malang. Penelitian ini menggunakan pendekatan kuantitatif, jenis penelitian ini adalah ex post facto. Metode statistik penelitian ini menggunakan regresi linier berganda. Populasi dalam penelitian ini adalah seluruh anggota Kopma Universitas Negeri Malang (UM) angkatan 2015-2017 sebesar 800 anggota, teknik pengambilan sampel penelitian menggunakan simple random sampling dengan jumlah 120 anggota. Teknik analisis data dalam penelitian ini menggunakan uji asumsi klasik diantaranya, uji normalitas, uji multikolonieritas, dan uji heterokesdastisitas. Analisis hasil data penelitian dengan menggunakan analisis SPSS versi 22.00 for windows. Hasil dari penelitian ini menunjukkan bahwa Pelatihan Perkoperasian secara simultan memiliki pengaruh terhadap Partisipasi Anggota di Kopma Universitas Negeri Malang, Kualitas Pelayanan secara simultan memiliki pengaruh terhadap Partisipasi Anggota di Kopma Universitas Negeri Malang, Kreatifitas Pengurus memiliki pengaruh terhadap Partisipasi Anggota Kopma Universitas Negeri Malang. Berdasarkan hasil analisis yang telah dikemukakan diatas maka dapat ditarik kesimpulan bahwa terdapat pengaruh yang signifikan secara simultan antara Pelatihan Perkoperasian,Kualitas Pelayanan dan Kreatifitas Pengurus Terhadap Partisipasi Anggota di Kopma Universitas Negeri Malang.
\end{abstract}

Kata kunci-Pelatihan, Pelayanan, Kreatifitas, Partisipasi Anggota.

ABSTRACT : This study aims to Analyze the Effect of Cooperative Training, Service Quality and Management Creativity on Member Participation in Kopma State University of Malang, Analyze the Effect of Cooperative Training on Member Participation in Kopma State University of Malang, Analyze Effect of Service Quality on Member Participation in Kopma Malang State University, and Analyzing the Effect of Management Creativity on Member Participation at Kopma State University of Malang. This research uses a quantitative approach, this type of research is ex post facto. The statistical method of this research uses multiple linear regression. The population in this study were all members of Kopma State University of Malang (UM) class of 2015-2017 amounting to 800 members, the research sampling technique used simple random sampling with a total of 120 members. Data analysis techniques in this study used a classic assumption test including the normality test, the multicollinearity test, and the heterokesdasticity test. Analysis of the results of research data using SPSS analysis version 22.00 for windows. The results of this study indicate that simultaneous Cooperative Training has an influence on Member Participation in Kopma Malang State University, Service 
Quality simultaneously has an influence on Member Participation in Kopma Malang State University, Management Creativity has an influence on Kopma Member Participation in Malang State University. Based on the analysis results stated above, it can be concluded that there is a significant simultaneous influence between Cooperative Training, Service Quality and Management Creativity on Member Participation at Kopma State University of Malang.

Keywords - Training, Service, Creativity, Member Participation.

\section{PENDAHULUAN}

Koperasi didefinisikan sebagai badan usaha yang beranggotakan orang yang berdasarkan badan hukum, dengan berlandaskan asas kekeluargaan (UU No. 25 Tahun 1992). Pernyataan tersebut menunjukkan bahwa koperasi mahasiswa merupakan koperasi yang didirikan oleh mahasiswa di berbagai jurusan. Oleh sebab itu mahasiswa diharapkan dapat berpartisipasi aktif kedalam Kopma. Apabila mahasiswa sudah memiliki rasa perhatian terhadap Kopma, maka akan semakin tinggi pula keputusan mahasiswa untuk berpartisipasi ke dalam sebuah Kopma. Pernyataan tersebut diperkuat oleh (Keith Davis 2011: 29) bahwa partisipasi anggota merupakan keikutsertaan seseorang dalam suatu organisasi tertentu yang mendorong seseorang tersebut memberikan partisipasinya dan bertanggung jawab atas organisasi tersebut. Selain itu mahasiswa juga diwajibkan untuk mengikuti pelatihan perkoperasian terlebih dahulu sebelum masuk kedalam Kopma.

Berdasarkan Undang-Undang Perkoperasian telah disebutkan bahwa pentingnya menyisihkan sebagian sisa hasil usaha koperasi berupa dana pendidikan yang tujuannya untuk pelaksanaan pelatihan perkoperasian. Bahkan dalam Undang-Undang Nomor 17 tahun 2012 tentang Perkoperasian pasal 6 ayat (e) telah dicantumkan bahwa salah satu prinsip koperasi yaitu "koperasi menyelenggarakan pendidikan dan pelatihan bagi seluruh anggota koperasi baik anggota, pengawas, pengurus, dan karyawannya, serta memberikan informasi kepada masyarakat tentang jati diri koperasi yang sesungguhnya".

Pentingnya tugas mahasiswa dalam sebuah koperasi. Maka, selain pelatihan yang menjadi daya tarik bagi mahasiswa untuk menjadi anggota Kopma, hal yang harus dilakukan oleh Kopma adalah meningkatkan kualitas pelayanannya dengan sebaik mungkin. Menurut Lupiyoadi (2014:7) kualitas pelayanan merupakan salah satu kegiatan yang dilakukan oleh karyawan guna memenuhi kebutuhan para pelanggan. Kualitas pelayanan bisa dikatakan baik apabila pelayanan yang diberikan oleh karyawan Kopma sesuai apa yang diharapkan oleh pelanggan. Hal ini dapat membuat semangat para karyawan dalam meningkatkan kualitas pelayanannya dengan sebaik mungkin. Selain kualitas pelayanan yang perlu diperhatikan oleh anggota, kreatifitas pengurus juga sangat dibutuhkan dalam membangun sebuah Kopma.

Kehidupan Kopma akan sangat lebih maju apabila dalam berkoperasi, pengurus memiliki kreatifitas yang tinggi. Karena jika pengurus memiliki kreatifitas yang tinggi, maka mereka akan lebih mudah dalam membuat suatu penemuan baru yang dapat mengembangkan suatu Kopma. Selain itu mereka akan lebih mudah mengembangkan kreatifitasnya dengan berbagai ide yang dimiliki oleh setiap individu. Sedangkan menurut Ngalimun dkk (2013: 45) kreatifitas merupakan kemampuan seseorang yang dapat memunculkan ide-ide baru guna menghasilkan suatu produk yang dapat dijual kedalam Kopma. Sehingga akan sangat berpengaruh terhadap berkembangnya suatu Kopma.

Akan tetapi saat ini realitanya untuk partisipasi anggota di Kopma UM masih belum optimal, dikarenakan jumlah anggota dari tahun ke tahun mengalami kenaikan namun diakhir tahun banyak yang dikeluarkan dari keanggotaan, karena mereka hanya mengikuti kegiatan Kopma diawal saja dan mereka lebih memilih UKM lain daripada mengikuti Kopma. Alasan mereka karena tidak mau terlalu banyak kegiatan, sehingga mereka memutuskan untuk berhenti dari keanggotaan Kopma dan 
memilih untuk mengikuti UKM lain. Kopma sendiri merupakan koperasi yang dipegang langsung oleh mahasiswa Universitas Negeri Malang (UM) dari berbagai fakultas dan program studi. Penelitian ini akan dilakukan di Kopma Universitas Negeri Malang (UM), karena di Kopma tersebut masih sedikit partisipasi mahasiswa untuk menjadi anggota Kopma.

\section{TINJAUAN PUSTAKA}

Partisipasi anggota merupakan salah satu kunci keberhasilan dalam meningkatkan kemajuan suatu koperasi (Kusnandi, 2010). Seseorang yang mempunyai partisipasi dalam suatu organisasi, maka akan cenderung memiliki ketertarikan yang lebih besar terhadap organisasi tersebut. Oleh karena itu sebelum masuk kedalam Kopma bagi calon anggota diharapkan mengikuti pelatihan perkoperasian terlebih dahulu, agar mereka memiliki pengetahuan yang luas tentang perkoperasian.

Koperasi menyelenggarakan pelatihan perkoperasian bagi anggota, pengawas, pengurus dan karyawannya serta memberikan informasi kepada masyarakat tentang jati diri dari koperasi yang sebenarnya. Hal ini sesuai dengan Undang-Undang Nomor 17 tahun 2012 tentang Perkoperasian pasal 6 ayat (e). Pendapat ini sejalan dengan penelitian yang dilakukan oleh Syintia Rahmah Hidayah, 2015 yang mengatakan bahwa "tidak ada pengaruh yang signifikan antara pelatihan perkoperasian terhadap partisipasi anggota". Selain pelatihan perkoperasian, kualitas pelayanan juga sangat dibutuhkan dalam mengembangkan sebuah Kopma, karena pelayanan yang baik akan membuat mahasiswa semakin tertarik untuk mengikuti organisasi ini.

Kualitas pelayanan diharapkan dapat memenuhi kebutuhan para pelanggan. (Tjiptono, 2011:59). Jika dilihat dari sudut pandang, kualitas adalah sebuah upaya yang dilakukan oleh karyawan Kopma dalam melayani pelanggan. Pelanggan akan memberikan nilai baik apabila karyawan dapat menciptakan pelayanannya dengan baik pula. Karena kepuasan pelanggan merupakan tolok ukur dalam berdirinya sebuah Kopma. Pendapat ini sejalan dengan penelitian yang dilakukan oleh Irawati, 2017 yang menyatakan bahwa "kualitas pelayanan berpengaruh positif terhadap partisipasi anggota". Selain pelatihan perkoperasian dan kualitas pelayanan yang harus diperhatikan oleh anggota, kreatifitas pengurus juga sangat berpengaruh penting terhadap Kopma.

Munandar (2011: 29) mengatakan bahwa kreatifitas adalah kemampuan seseorang dalam mengembangkan sebuah ide sesuai dengan kemampuan yang dimilikinya. Munandar mendefinisikan kreatifitas sebagai penemuan baru dalam mengembangkan sebuah ide yang dimiliki oleh setiap individu. Pengurus yang kreatif akan lebih mudah membuat produk-produk baru, karena mereka memiliki kreatifitas yang tinggi. Pendapat ini sejalan dengan penelitian yang dilakukan oleh Odhiansyah, 2016 yang menyatakan bahwa "kreatifitas pengurus memiliki pengaruh yang signifikan terhadap partisipasi anggota". Sehingga dalam pendapat tersebut akan memunculkan sebuah hipotesis penelitian.

\section{METODE}

Metode yang digunakan dalam penelitian ini yaitu dengan menggunakan metode kuantitatif. Analisis ini bertujuan untuk mengetahui seberapa besar pengaruh variabel bebas (Pelatihan perkoperasian, kualitas pelayanan dan kreatifitas pengurus) terhadap variabel terikat (partisipasi anggota) jika keempat variabel tersebut memiliki pengaruh yang signifikan.

Ruang lingkup dari penelitian ini yaitu untuk menganalisis apakah terdapat pengaruh yang signifikan antara pelatihan perkoperasian, kualitas pelayanan dan kreatifitas pengurus terhadap partisipasi anggota di Kopma Universitas Negeri Malang (UM). Penelitian ini hanya terbatas untuk anggota Kopma UM angkatan 2015-2017.

Populasi yang digunakan dalam penelitian ini adalah seluruh anggota Kopma Universitas Negeri Malang (UM) angkatan 2015-2017 sebanyak 800 anggota yang terdiri dari berbagai jurusan. Penelitian ini menggunakan teknik probability sampling dengan jenis simple random sampling dan 
pengambilan sampel yang digunakan sebesar 120 anggota, jadi sampel yang diambil sebesar 15\% dengan dilakukan secara acak. Dan teknik pengambilan sampel ini peneliti menggunakan angket. Metode yang digunakan dalam analisis ini adalah dengan mengggunakan analisis regresi berganda.

\section{HASIL DAN PEMBAHASAN}

Hasil penelitian ini diperoleh dari pengumpulan data dengan menggunakan skala likert. Pemaparan tersebut meliputi: pelatihan perkoperasian, kualitas pelayanan, kreatifitas pengurus dan partisipasi anggota di Koperasi Mahasiswa Universitas Negeri Malang (UM) yang mencakup mean, median, mode, standart deviation, variance, range, skor minimum, skor maximum, dan sum Y. variabel terikat (partisipasi anggota) dengan disajikan pada Tabel sebagai berikut :

Tabel 1

Skor Data Empirik Variabel Penelitin

\begin{tabular}{lllll}
\hline & TOTAL Y & TOTAL X1 & TOTAL X2 & TOTAL X3 \\
\hline N Valid & 120 & 120 & 120 & 120 \\
$\quad$ Missing & 0 & 0 & 0 & 0 \\
Mean & 20.34 & 73.12 & 97.49 & 42.15 \\
Median & 20.00 & 72.00 & 99.00 & 42.00 \\
Mode & $13.00^{a}$ & 72.00 & 100.00 & 42.00 \\
Std. Deviation & 7.46 & 11.18 & 13.07 & 5.34 \\
Variance & 55.70 & 125.18 & 171.07 & 28.59 \\
Range & 28.00 & 72.00 & 74.00 & 29.00 \\
Minimum & 7.00 & 18.00 & 51.00 & 25.00 \\
Maximum & 35.00 & 90.00 & 125.00 & 54.00 \\
Sum & 2441.00 & 8775.00 & 11699.00 & 5058.00 \\
\hline
\end{tabular}

Hasil perhitungan statistik dihitung dengan menggunakan bantuan software SPSS 22.00 for windows. Adapun hasil uji F dapat dilihat pada Tabel 2 sebagai berikut :

Tabel 2 Hasil Uji F (Uji Secara Simultan)

\begin{tabular}{ccccccc}
\hline \multicolumn{7}{c}{ ANOVA $^{\mathrm{a}}$} \\
\hline \multirow{3}{*}{1} & Model & Sum of Square & Df & Mean Square & F & Sig. \\
\cline { 2 - 7 } & Regression & 3037.553 & 3 & 1012.518 & 32.703 &, $000^{\mathrm{b}}$ \\
\cline { 2 - 8 } & Residual & 3591.439 & 116 & 30.961 & & \\
\cline { 2 - 8 } & Total & 6628.992 & 119 & & & \\
\hline
\end{tabular}

Berdasarkan Tabel 2 hasil Uji F meliputi: tes Anova diperoleh nilai F sebesar 32,703 dengan tingkat signifikan $0,000^{\mathrm{b}}$ karena tingkat signifikan lebih kecil dari 0,05 , maka $\mathrm{H}_{01}$ ditolak dan $\mathrm{H}_{\mathrm{a}}$ diterima artinya bahwa Pelatihan Perkoperasian $\left(X_{1}\right)$, Kualitas Pelayanan $\left(X_{2}\right)$, Kreatifitas Pengurus $\left(\mathrm{X}_{3}\right)$, secara bersama-sama memiliki pengaruh yang kuat terhadap Partisipasi Anggota ( $\mathrm{Y}$ ) pada anggota koperasi mahasiswa Universitas Negeri Malang (UM) angkatan 2015-2017.

Pelatihan perkoperasian merupakan hal yang penting dalam pengembangan koperasi karena keberhasilan atau kegagalan suatu koperasi bergantung pada tingkat pelatihan yang dampaknya akan meningkatkan partisipasi anggota. Oleh karena itu sebelum masuk menjadi anggota Kopma, mahasiswa harus mengikuti pelatihan perkoperasian terlebih dahulu yang tujuannya adalah untuk memberikan bekal dasar kepada calon anggota Kopma agar mereka dapat memahami peran dan tugasnya sebagai anggota Kopma di masa yang akan datang.

Selain pelatihan perkoperasian, kualitas pelayanan juga sangat mempengaruhi keputusan mahasiswa untuk bergabung ke dalam Kopma. Pelayanan yang baik akan mempengaruhi mahasiswa 
untuk semakin tinggi keinginannya masuk ke dalam Kopma. Oleh karena itu karyawan Kopma Universitas Negeri Malang (UM) selalu berusaha memberikan pelayanannya dengan sebaik mungkin, agar mahasiswa merasa nyaman ketika berbelanja di Kopma. Selain itu mahasiswa juga merasa senang ketika karyawan Kopma bersikap ramah. Apabila mahasiswa sudah mengetahui kualitas pelayanan yang diciptakan oleh pengurus Kopma sudah baik, maka akan semakin meningkatkan partisipasi mahasiswa untuk mengikuti anggota Kopma. Hal ini terbukti ketika peneliti melakukan observasi terdahulu masih banyak mahasiswa yang berbelanja di Kopma.

Sama seperti halnya dengan pelatihan perkoperasian dan kualitas pelayanan, kreatifitas pengurus juga menjadi faktor yang dapat mempengaruhi partisipasi anggota Kopma. Pengurus yang kreatif akan lebih mudah untuk menghasilkan ide-ide baru yang nantinya akan digunakan dalam mengembangkan kegiatan perkoperasian yang tujuannya untuk memenuhi keinginan para anggotanya. Dengan demikian akan lebih banyak mahasiswa yang mau berpartisipasi kedalam Kopma. Karena pada dasarnya kegiatan perkoperasian tidak akan lancar apabila pengurus tidak memiliki kreatifitas.

Anggota kopma yang sudah mengikuti pelatihan perkoperasian dengan baik, sudah mengetahui kualitas pelayanan yang diberikan oleh karyawan juga baik dan memiliki kreatifitas yang tinggi, maka sudah dapat dipastikan bahwa anggota Kopma tersebut nantinya akan lebih mudah mengembangkan koperasi dan dapat bersaing secara sehat dengan Kopma-kopma yang lainnya. Oleh karena itu, Pelatihan Perkoperasian, Kualitas Pelayanan dan Kreatifitas Pengurus secara bersama-sama akan berpengaruh terhadap Partisipasi Anggota di Kopma Universitas Negeri Malang (UM) yang dalam penelitian ini khususnya untuk anggota Kopma UM angkatan 2015-2017.

Berdasarkan nilai $\mathrm{R}^{2}$ untuk mengukur besarnya proporsi dari variabel bebas yaitu dengan menggunakan Regresi Linier Berganda. Semakin tinggi nilai $\mathrm{R}^{2}$ maka semakin baik model regresi dalam menentukan berpengaruh atau tidaknya variabel bebas terhadap variabel terikat. Hasil Uji $\mathrm{R}^{2}$ dapat dilihat pada Tabel 3 sebagai berikut:

Tabel 3 Uji R ${ }^{2}$

\begin{tabular}{lllll}
\hline \multicolumn{5}{c}{ Model Summary $^{\mathrm{b}}$} \\
\hline Model & $\mathrm{R}$ & R Square & Adjusted R Square & $\begin{array}{l}\text { Std. Error of } \\
\text { the Estimate }\end{array}$ \\
\hline 1 &, $677^{\mathrm{a}}$ &, 458 &, 444 & 5,56423 \\
\hline
\end{tabular}

Sumber: Hasil olahan SPSS versi 22.00 for windows

Berdasarkan Tabel 3 telah diketahui bahwa pengaruh antara variabel Pelatihan Perkoperasian $\left(X_{1}\right)$, Kualitas Pelayanan $\left(X_{2}\right)$, dan Kreatifitas Pengurus $\left(X_{3}\right)$ memiliki tingkat koefisien korelasi sebesar 0,667 diatas 50\% untuk mencapai angka 1,artinya variabel bebas Pelatihan Perkoperasian $\left(X_{1}\right)$, Kualitas Pelayanan $\left(X_{2}\right)$, dan Kreatifitas Pengurus $\left(X_{3}\right)$ secara bersama-sama memiliki hubungan yang kuat dengan variabel terikat Partisipasi Anggota (Y). Sedangkan nilai koefisien determinasi (R Square) menunjukkan besarnya kontribusi seluruh variabel bebas antara Pelatihan Perkoperasian $\left(X_{1}\right)$, Kualitas Pelayanan $\left(X_{2}\right)$, Kreatifitas Pengurus $\left(X_{3}\right)$ terhadap Partisipasi Anggota ( $\mathrm{Y}$ ), jadi $\mathrm{R}$ Square 0,458 memiliki arti bahwa Pelatihan Perkoperasian $\left(\mathrm{X}_{1}\right)$, Kualitas Pelayanan $\left(X_{2}\right)$ dan Kreatifitas Pengurus $\left(X_{3}\right)$ mampu memberikan kontribusi sebesar 45,8\% terhadap Partisipasi Anggota (Y).

Berdasarkan data yang dihasilkan oleh uji t yang akan digunakan untuk mengetahui apakah data yang dihasilkan signifikan dan berpengaruh antara variabel independen yang terdiri dari Pelatihan Perkoperasian $\left(X_{1}\right)$, Kualitas Pelayanan $\left(X_{2}\right)$ dan Kreatifitas Pengurus $\left(X_{3}\right)$ terhadap variabel dependen yaitu Partisipasi Anggota (Y). Hasil uji t pada penelitian ini dapat dilihat pada Tabel 4 sebagai berikut: 
Tabel 4 Hasil Uji t (Uji Signifikan Parsial)

\begin{tabular}{clccc}
\hline \multicolumn{5}{c}{ Coefficients $^{\mathbf{a}}$} \\
\hline \multirow{3}{*}{1} & Model & $\mathrm{T}$ & Sig. & Keterangan \\
\cline { 2 - 5 } & \multicolumn{1}{c}{ (Constant) } & $-5,272$ &, 000 & Signifikan \\
\cline { 2 - 5 } & $\mathrm{X}$ (Pelatihan Perkoperasian) &, 942 &, 348 & Tidak Signifikan \\
\cline { 2 - 5 } & $\mathrm{X}$ 2 (Kualitas Pelayanan) & 2,405 &, 018 & Signifikan \\
\cline { 2 - 5 } & $\mathrm{X}$ 3 (Kreatifitas Pengurus) & 4,647 &, 000 & Signifikan \\
\hline
\end{tabular}

Sumber: Hasil olahan SPSS 22.00 for windows

Berdasarkan Tabel 4 hipotesis penelitian digunakan untuk menguji hipotesis kedua $\left(\mathrm{H}_{2}\right)$ yaitu sebagai berikut : berdasarkan hasil analisis diperoleh nilai thitung sebesar 0,942 dengan nilai sig. 0,348 lebih besar dari 0,05 yang artinya bahwa Pelatihan Perkoperasian $\left(X_{1}\right)$ tidak signifikan terhadap Partisipasi Anggota (Y) pada koperasi mahasiswa Universitas Negeri Malang (UM) angkatan 20152017. Hal ini disebabkan karena kebanyakan responden yang menjawab pertanyaan hanya mengikuti pelatihan di awal saja namun di akhir tahun banyak yang dikeluarkan dari keanggotaan Kopma. Sehingga menyebabkan data yang diolah menghasilkan tidak terjadi signifikansi antara variabel pelatihan perkoperasian terhadap partisipasi anggota. Selain itu berdasarkan jawaban dari responden menyatakan bahwa mereka kebanyakan sudah mengikuti pelatihan perkoperasian namun belum mampu mengimplementasikan ilmu yang didapat selama menjadi anggota Kopma.

Selain itu dengan diadakannya pelatihan perkoperasian, maka calon anggota Kopma akan semakin paham dan mengerti mengenai peran dan tugas penting dari koperasi itu sendiri khususnya koperasi mahasiswa. Demikian juga sebaliknya apabila calon anggota mengetahui dengan baik keberadaan Kopma, akan tetapi perkembangan dari Kopma tersebut kurang baik maka dapat dipastikan calon anggota tersebut akan mundur dan tidak jadi berpartisipasi kedalam Kopma. Karena ketika calon anggota Kopma mengikuti kegiatan pelatihan perkoperasian, mereka akan mendapatkan pengetahuan yang luas tentang dunia perkoperasian. Dengan demikian Pelatihan Perkoperasian memiliki pengaruh terhadap Partisipasi Anggota di Koperasi Mahasiswa Universitas Negeri Malang (UM) secara simultan sedangkan secara parsial tidak memiliki pengaruh yang signifikan karena nilai signifikan lebih besar dari 0,05.

Hipotesis penelitian selanjutnya digunakan untuk menguji hipotesis ketiga $\left(\mathrm{H}_{3}\right)$ yaitu sebagai berikut: berdasarkan hasil analisis diperoleh nilai thitung sebesar 2,405 dengan nilai sig. 0,018 lebih kecil dari 0,05 artinya bahwa Kualitas Pelayanan $\left(\mathrm{X}_{2}\right)$ berpengaruh signifikan terhadap Partisipasi Anggota (Y) pada anggota koperasi mahasiswa Universitas Negeri Malang (UM) angkatan 2015-2017. Hasil penelitian ini sejalan dengan penelitian yang dilakukan oleh Aprilia Widyastuti, 2013 yang berjudul "Pengaruh Pengetahuan Anggota tentang Koperasi dan Kualitas Pelayanan terhadap Partisipasi Anggota pada Koperasi Serba Usaha (KSU) Warga Sejahtera, Kelurahan Cipinang, Jakarta Timur." Hasil penelitian ini mengatakan bahwa terdapat pengaruh yang signifikan antara kualitas pelayanan terhadap partisipasi anggota. Kualitas pelayanan juga merupakan suatu hal yang harus dipahami oleh setiap anggota 
Kopma. Jika anggota sudah memahami kualitas pelayanan yang diberikan oleh karyawan Kopma baik maka akan semakin banyak pula anggota Kopma yang memberikan kontribusinya terhadap Kopma itu sendiri. Dengan demikian maka Kopma akan semakin banyak anggotanya dan akan semakin meningkat setiap tahunnya. Karena selama ini Kopma Universitas Negeri Malang (UM) belum pernah mendapatkan pengaduan yang berhubungan dengan kualitas pelayanan. Maka sudah dapat dipastikan bahwa karyawan Kopma Universitas Negeri Malang sudah mampu menciptakan pelayanannya dengan sebaik mungkin, terutama pelayanan yang diberikan kepada pelanggan misalnya: memberikan bantuan kepada anggota atau pelanggan jika pada saat berbelanja di Kopma mengalami kesulitan dan bersikap ramah pada saat melayani anggota. Dengan cara itu maka anggota akan merasa senang ketika berkecimpung kedalam Kopma.

Berdasarkan dari jawaban responden dapat menunjukkan bahwa di Kopma Universitas Negeri Malang kualitas pelayanan yang diberikan oleh karyawan Kopma sudah baik, terbukti masih banyak yang berbelanja di Kopma. Selain itu, dengan keberadaan Kopma dapat memberikan kepercayaan bagi anggota bahwa pelayanan yang diberikan oleh Kopma Universitas Negeri Malang sudah bagus.

Oleh karena itu dapat disimpulkan bahwa kualitas pelayanan yang diciptakan oleh Kopma Universitas Negeri Malang memiliki pengaruh yang besar terhadap partisipasi anggota. Selain itu dari karyawan sendiri selalu berusaha agar kualitas pelayanan yang diberikan bisa mengimbangi kepercayaan anggota terhadap Kopma. Dengan cara selalu menyediakan barang-barang yang dibutuhkan oleh anggota Kopma, sehingga Kopma tidak diremehkan oleh anggota atau masyarakat dan dianggap sebagai organisasi yang besar.

Hipotesis penelitian yang keempat $\left(\mathrm{H}_{4}\right)$ adalah sebagai berikut: berdasarkan hasil analisis diperoleh nilai thitung sebesar 4,647 dengan nilai sig. 0,000 lebih kecil dari 0,05 yang artinya bahwa Kreatifitas Pengurus $\left(\mathrm{X}_{3}\right)$ berpengaruh signifikan terhadap Partisipasi Anggota ( $\mathrm{Y}$ ) pada Koperasi Mahasiswa Universitas Negeri Malang (UM) angkatan 2015-2017.

Kreatifitas pengurus juga memiliki pengaruh yang sangat penting terhadap perkembangan Kopma Universitas Negeri Malang (UM). Oleh karena itu sangat diperlukan bagi Kopma agar pengurus yang memiliki ide kreatif dapat mengembangkan idenya dengan sekreatif mungkin. Dengan demikian anggota Kopma yang lain akan lebih aktif memberikan idenya demi kelancaran kegiatan Kopma selanjutnya.

Berdasarkan pertanyaan yang diajukan oleh peneliti melalui kuesioner atau angket, banyak anggota Kopma yang memiliki ide kreatif dalam mengembangkan Kopma. Mereka memperoleh ide tersebut setelah termotivasi oleh pengurus Kopma. Selain itu mereka juga dapat menciptakan suatu produk yang bisa dijual di dalam Kopma, karena di dalam Kopma anggota harus memiliki kreatifitas yang tinggi.

Kopma harus memberikan banyak manfaat bagi anggota dan mahasiswa, sehingga anggota dan mahasiswa akan memiliki kreatifitas tersendiri. Jika mahasiswa khususnya anggota Kopma mendapatkan manfaat yang banyak maka anggota tersebut akan memberikan yang terbaik untuk Kopma yang sedang diikutinya. Dengan menjadi keanggotaan Kopma, anggota yang lain bisa mendapatkan pengalaman dibidang perkoperasian. Dapat disimpulkan bahwa Kreatifitas Pengurus memiliki pengaruh yang signifikan terhadap Partisipasi Anggota Kopma Universitas Negeri Malang (UM).

\section{KESIMPULAN}

Berdasarkan hasil analisis yang telah dikemukakan pada bab V, maka dapat disimpulkan bahwa terdapat pengaruh yang signifikan secara simultan antara Pelatihan Perkoperasian, Kualitas Pelayanan dan Kreatifitas Pengurus terhadap Partisipasi Anggota di Kopma Universitas Negeri Malang, karena tingkat signifikansi memenuhi syarat yang artinya variabel Pelatihan Perkoperasian, 
Kualitas Pelayanan dan Kreatifitas Pengurus memiliki pengaruh yang signifikan terhadap Partisipasi Anggota Kopma. Pada Pelatihan Perkoperasian tidak terdapat pengaruh yang signifikan secara parsial terhadap Partisipasi Anggota Kopma. Kualitas Pelayanan mempunyai pengaruh yang signifikan secara parsial terhadap Partisipasi Anggota Kopma. Dan Kreatifitas Pengurus juga memiliki pengaruh yang signifikan secara parsial terhadap Partisipasi Anggota di Kopma Universitas Negeri Malang (UM).

Berdasarkan kesimpulan diatas, maka saran yang diajukan oleh peneliti kepada seluruh pihak yakni sebaiknya Kopma dapat memberikan pelatihan secara khusus kepada mereka calon anggota Kopma UM, hal ini bertujuan agar calon anggota memiliki pengetahuan dasar tentang perkoperasian sehingga mereka akan semakin paham tentang jati diri Kopma yang sebenarnya. Selain itu untuk meningkatkan kualitas pelayanannya diharapkan pengurus harus mampu menciptakan komunikasi yang baik dengan para pelanggan. Misalnya, sistem pelayanan yang diberikan selalu menarik dan selalu bersikap ramah dan sopan kepada anggota Kopma yang lain. Untuk meningkatkan kreatifitas pengurus, anggota Kopma harus memiliki kreatifitas. Dimana kreatifitas merupakan kemampuan yang dimiliki oleh seseorang untuk menghasilkan sebuah karya baru yang tujuannya untuk mengembangkan kehidupan Kopma dimasa yang akan datang. Dengan demikian anggota yang lain akan aktif memberikan kontribusinya terhadap Kopma.

\section{DAFTAR PUSTAKA}

Arikunto, Suharsimi. 2010. Prosedur Penelitian Suatu Pendekatan Praktik. Jakarta: Rineka Cipta

Davis, Keith, 2011, Pengertian Partisipasi Anggota, Edisi Ketujuh, Penerbit. Erlangga, Jakarta.

Hasan. 2008. Analisis Regresi Berganda. Jakarta: Erlangga.

Hidayah, Rahmah Syintia, 2015. Pengaruh Pelatihan Perkoperasian Dan Kemampuan Manajerial Pengurus Terhadap Partisipasi Anggota Koperasi Jasa Keuangan Syariah (KJKS) Nu Graha Ungaran. Jurnal Pendididkan Ekonomi volume 4, 134-256 2015

Irawati, 2017. Pengaruh Kualitas Pelayanan Koperasi dan Perkembangan Usaha Koperasi Terhadap Partisipasi Anggota Koperasi Berkah Karya Mandiri Puri Mayang Kota Jambi. Jurnal Pendidikan Ekonomi volume 4, 267-235 2017

Kusnandi, 2010. Ekonomi Koperasi, Jakarta: Erlangga.

Lupiyoadi. (2014:7). Manajemen usaha . Jakarta: Salemba Empat.

Munandar, Utami (2011). Pengertian Kreatifitas. Jakarta: PT. Gramedia.

Ngalimun, dkk. (2013). Perkembangan dan Pengembangan Kreatifitas. Yogyakarta: Aswaja Pressindo.

Sugiyono. (2010). Metode Penelitian Kuantitatif, Kualitatif \& RND. Bandung: Alfabeta.

Sugiyono, 2013. Metode Penelitian Pendidikan, Alfabeta, Bandung.

Sugiyono, 2017. Metode Penelitian Kuantitatif, Kualitatif dan RED. Bandung: Alfabeta.

Tjiptono, 2011. Service Quality and Satisfaction. Edisi 3. Andi Offset. Yogyakarta.

Odhiansyah, Tri Nofanda 2016. The Effects Of Member's Knowledge Of Cooperative, Managerial Personnel's Creativity, And Member's Motivation On The Participation Of Members Of The Student Cooperative Of Yogyakarta State University. Jurnal Pendidikan Ekonomi 5(4), 275-282, 2016

Undang-Undang RI Nomor 25 Tahun 1992 Tentang Koperasi

Undang-Undang Nomor 17 Pasal 6 ayat (e) Tahun 2012 Tentang Perkoperasian 
Pengaruh Pelatihan Perkoperasian, Kualitas Pelayanan Dan Kreatifitas Pengurus Terhadap Partisipasi Anggota Koperasi Mahasiswa Universitas Negeri Malang (UM)

Widyastuti, Aprilia, 2013. Pengaruh Pengetahuan Anggota Koperasi dan Kualitas Pelayanan terhadap Partisipasi Anggota pada Koperasi Serba Usaha (KSU) Warga Sejahtera, Kelurahan Cipinang, Jakarta Timur. Jurnal Pendidikan Ekonomi Dan Bisnis (JPEB) 1 (1), 62-76, 2013 